\title{
Investigation and Analysis on the Influencing Factors of College Students' Entrepreneurial Intention
}

\author{
Kangli Liao \\ Accounting College, Jiujiang University, Jiujiang City, China \\ Email address: \\ liaokangli@126.com \\ To cite this article: \\ Kangli Liao. Investigation and Analysis on the Influencing Factors of College Students' Entrepreneurial Intention. Teacher Education and \\ Curriculum Studies. Vol. 5, No. 3, 2020, pp. 108-113. doi: 10.11648/j.tecs.20200503.19
}

Received: July 11 2020; Accepted: July 27, 2020; Published: August 5, 2020

\begin{abstract}
College students are full of entrepreneurial passion and possess entrepreneurial knowledge reserve and potential. In order to understand the basic situation of College Students' entrepreneurial intention in detail, this paper adopts the research method of questionnaire survey, taking Jiujiang University Students as the survey object, and makes an empirical analysis on the influencing factors of College Students' entrepreneurial intention. The results show that the overall level of College Students' entrepreneurial willingness is high, but the proportion of entrepreneurial practice is low. Male students have higher entrepreneurial willingness than female students. College students with different professional backgrounds have different entrepreneurial intentions. Entrepreneurship education has a positive effect on the promotion of entrepreneurial willingness. The current entrepreneurial activities are mainly survival oriented entrepreneurship, with intellectual property as the main entrepreneurship The proportion of business model innovation is low. In order to further enhance the entrepreneurial willingness of college students and realize the transformation from entrepreneurial intention to entrepreneurial action, universities, government and society should work together: colleges and universities should strengthen entrepreneurship education and improve the effectiveness of entrepreneurship services; the government should strengthen the publicity and implementation of relevant policies; the whole society should establish a public opinion environment that encourages entrepreneurship and tolerates failure.
\end{abstract}

Keywords: Entrepreneurial Willingness, College Students, Entrepreneurship Education

\section{Introduction}

College students are a group full of entrepreneurial passion. Entrepreneurial intention is a subjective attitude of potential entrepreneurs on whether to engage in entrepreneurial activities or not [1]. It is also a general description of people's entrepreneurial attitude and ability. With the development of market economy and the expansion of colleges and universities, college students' Entrepreneurship and corresponding entrepreneurship education are highly valued by the government, enterprises and universities. According to the theory of planned behavior, all factors that may affect behavior indirectly affect behavior performance through behavioral intention. Therefore, college students' entrepreneurial intention plays a decisive role in their future choice of entrepreneurship. Willingness is a kind of subjective desire, which is the psychological motivation of an individual to put his conscious plan or decision into action in order to achieve a specific goal [2]. Among the existing research results on entrepreneurial intention, scholars have diversified perspectives. Duan Limin and Du Yueping empirically tested the impact of entrepreneurial environment on College Students' entrepreneurial intention [3]; Tan Liwen et al. and $\mathrm{Xu}$ Jing studied the impact of entrepreneurship education on College Students' entrepreneurial intention [4, 5]. Bai Yu established the influence system model of College Students' entrepreneurial intention [6], while Shi Yongchuan et al. discussed the influence of College Students' own creation on College Students' entrepreneurial intention [7]. Based on the relevant research of the above scholars, this paper will use the survey method to understand the influencing factors of College Students' entrepreneurial intention from a broader perspective, so as to better guide college students to actively improve their entrepreneurial and innovative ability. 


\section{Research Object and Method}

This paper takes the students of Jiujiang University as the research object, involving 1051 students from 8 colleges, including College of economics and management, College of ecommerce, College of accounting, College of culture and media, College of medical, College of machinery and materials, College of Electronic Engineering, College of information engineering and technology. The characteristics of the study samples are shown in Table 1.

Table 1. Basic information of research samples.

\begin{tabular}{|c|c|c|c|}
\hline \multicolumn{2}{|c|}{ Sample category } & \multirow{2}{*}{$\begin{array}{l}\text { Number of people } \\
507\end{array}$} & \multirow{2}{*}{$\begin{array}{l}\text { Proportion (\%) } \\
48.33\end{array}$} \\
\hline & male & & \\
\hline Gender & female & 543 & 51.67 \\
\hline \multirow{5}{*}{ Grade } & Freshman & 251 & 23.88 \\
\hline & Sophomore & 201 & 19.12 \\
\hline & Junior & 223 & 21.22 \\
\hline & Senior & 376 & 35.78 \\
\hline & College of economics and management & 101 & 9.61 \\
\hline \multirow{6}{*}{ College } & College of accounting & 187 & 17.79 \\
\hline & College of culture and media & 82 & 7.80 \\
\hline & College of medical & 132 & 12.56 \\
\hline & College of machinery and materials & 123 & 11.70 \\
\hline & College of Electronic Engineering & 125 & 11.89 \\
\hline & College of information engineering and technology & 168 & 15.98 \\
\hline Total & & 1051 & 100 \\
\hline
\end{tabular}

\section{Analysis of Survey Results}

\subsection{The Overall Situation of College Students' Participation in Entrepreneurial Activities}

We have set up six options on College Students awareness of entrepreneurship and entrepreneurial activities. The survey results are shown in Table 2.

Table 2. The overall situation of College Students' participation in entrepreneurial activities.

\begin{tabular}{|c|c|c|}
\hline Option & Number of people & Proportion (\%) \\
\hline I'm not interested in starting a business. I'm not ready to start a business in the future & 165 & 15.70 \\
\hline Interested in starting a business, but not ready to start a business in the future & 328 & 31.21 \\
\hline I'm not interested in starting a business, but I'm still ready to start a business in the future & 63 & 5.99 \\
\hline Interested in starting a business, and have plans to start a business in the future & 416 & 39.58 \\
\hline Entrepreneurial activities have been launched, but are not intended to continue & 8 & 0.76 \\
\hline Entrepreneurship activities have been launched and intend to continue & 70 & 6.66 \\
\hline Total & 1051 & 100 \\
\hline
\end{tabular}

It can be seen from table 2 that a high proportion of respondents are interested in entrepreneurship, accounting for 77.53 in total. This shows that under the influence of the environment of "mass entrepreneurship and innovation" and the environment of entrepreneurship education in Colleges and universities, the entrepreneurial concept and awareness have gradually become popular. Among them, 31.21\% of the respondents chose "interested in entrepreneurship, but not ready to start a business in the future", said. In addition, although these respondents said that they would not be ready to start a business in the future, the formation of entrepreneurial concept and entrepreneurial awareness is also conducive to the formation of their employment concept and professional awareness. $21.69 \%$ of the respondents were not interested in starting a business, and $5.99 \%$ of them chose "not interested in starting a business, but still ready to start a business in the future". From the perspective of the respondents' entrepreneurial activities, only 70 people, accounting for only $6.66 \%$, actually put into entrepreneurial activities, and some entrepreneurs expressed their unwillingness to continue to start their own businesses. This shows that at present, there are many college students who have entrepreneurial intention, but the proportion who are engaged in entrepreneurial activities and can be sustained is too small.

\subsection{Gender Factors of College Students' Participation in Entrepreneurial Activities}

The results show that gender role differences lead to significant differences in college students' participation in entrepreneurial activities (see Table 3). Among the respondents, there is a significant difference between male and female students in entrepreneurial activities $\left(x^{2}=78.21\right.$, $\left.\mathrm{df}=2, \mathrm{P}=0.00^{* *}\right)$. Combining with the percentage, $42.41 \%$ of male students are interested in Entrepreneurship and are ready to start a business in the future, while only $6.41 \%$ of female students are interested in entrepreneurship 37\% are interested in starting a business and are ready to start a business in the future. On the whole, the enthusiasm of female students to participate in entrepreneurial activities is significantly less than that of male students. 
Table 3. Gender factors of College Students' participation in entrepreneurial activities.

\begin{tabular}{lllll}
\hline Gender & Number of people & Interested in starting a business, and have plans to start a business in the future & Proportion (\%) & $\mathbf{X}^{2}$ Test \\
\hline Male & 507 & 313 & 61.73 & \\
$\times$ & $2=78.21$ \\
Female & 543 & 103 & 18.97 & $\mathrm{df}=2$ \\
Total & 1051 & 416 & 39.58 & $\mathrm{P}=0.00^{* *}$ \\
\hline
\end{tabular}

* The difference is significant $(\mathrm{P}<0.05)$; ** The difference is very significant $(\mathrm{P}<0.01)$.

\subsection{The Influence of Major on College Students' Entrepreneurial Intention}

Through SPSS25.0 The results show that there are significant differences in the enthusiasm of students from different majors $\left(\mathrm{x}^{2}=66.38, \mathrm{df}=6.5, \mathrm{P}=0.01^{* *}\right)$. Combining with the percentage of students of different majors participating in entrepreneurial activities, $21.9 \%$ of science and engineering students actively participate in entrepreneurship related activities, while $35.3 \%$ of economic and management students actively participate in entrepreneurship, while only
$10.9 \%$ of students of Humanities and Social Sciences actively participate in entrepreneurship Entrepreneurial activities. The survey data preliminarily show that the students majoring in economics and management have the highest enthusiasm to participate in entrepreneurial activities, which is significantly higher than those of other majors such as science and engineering, humanities and Social Sciences, and their entrepreneurial intention is significantly higher than that of other majors (Table 4).

Table 4. The influence of major on College Students' entrepreneurial intention.

\begin{tabular}{llll}
\hline Major & Number of people & $\begin{array}{l}\text { Interested in starting a business, and have } \\
\text { plans to start a business in the future }\end{array}$ & $\begin{array}{l}\text { Proportion (\%) } \\
\mathbf{X}^{2} \text { Test }\end{array}$ \\
\hline Science and Engineering & 416 & 122 & 29.33 \\
Economics and management & 421 & 274 & 65.08 \\
Humanities and Social Sciences & 82 & 9 & 10.98 \\
Others & 132 & 11 & 8.33 \\
Total & 1051 & 416 & 39.58 \\
\hline
\end{tabular}

* The difference is significant $(\mathrm{P}<0.05) ; * *$ The difference is very significant $(\mathrm{P}<0.01)$.

\subsection{Entrepreneurial Education Factors of College Students' Participation in Entrepreneurial Activities}

Taking "whether you have participated in the entrepreneurship plan competition" as the representative of the entrepreneurship education of college students, through the statistical analysis of spss 25.0 , we can see that the difference between the students who have participated in the entrepreneurship plan competition and those who have not participated in the entrepreneurship plan competition is extremely significant $\left(\mathrm{x}^{2}=172.13\right.$, df $\left.=1.6, \mathrm{P}=0.00 * *\right)$. The entrepreneurial plan competition and other activities are helpful to enhance the entrepreneurial intention of students. The entrepreneurial intention of students who have participated in the entrepreneurship plan competition is significantly higher than that of the students who have not participated in the entrepreneurship plan competition (Table 5).

Table 5. Entrepreneurial education factors of College Students' participation in entrepreneurial activities.

\begin{tabular}{|c|c|c|c|c|}
\hline Option & $\begin{array}{l}\text { Number of } \\
\text { people }\end{array}$ & $\begin{array}{l}\text { Interested in starting a business, and have } \\
\text { plans to start a business in the future }\end{array}$ & $\begin{array}{l}\text { Proportion } \\
(\%)\end{array}$ & $\mathrm{X}^{2}$ Test \\
\hline Participated in the business plan competition & 621 & 322 & 51.85 & $\mathrm{X}^{2}=172.13$ \\
\hline I haven't participated in the business plan competition & 430 & 94 & 21.86 & $\mathrm{Df}=1.6$ \\
\hline
\end{tabular}

* The difference is significant $(\mathrm{P}<0.05) ; * *$ The difference is very significant $(\mathrm{P}<0.01)$.

\subsection{Types of Entrepreneurship of College Students}

We investigated the basic types of entrepreneurship of 70 respondents who have carried out entrepreneurial activities. We divided the entrepreneurial types into three types: survival entrepreneurship, imitation entrepreneurship and innovative entrepreneurship. Among them, survival entrepreneurship mainly refers to entrepreneurial activities with the main purpose of meeting the needs of survival and life, while imitative entrepreneurship mainly refers to the business model of existing mature enterprises Innovative entrepreneurship mainly refers to the entrepreneurial activities in which intellectual property rights are used as the main elements of entrepreneurship or business model innovation. The results are shown in Table 6.

Table 6. The basic types of College Students' Entrepreneurship.

\begin{tabular}{lll}
\hline Option & Number of people & Proportion (\%) \\
\hline Survival entrepreneurship & 20 & 29.06 \\
Imitation entrepreneurship & 38 & 54.35 \\
Innovative entrepreneurship & 12 & 16.58 \\
Total & 70 & 100 \\
\hline
\end{tabular}

As can be seen from table 6, at present, when students start their own businesses, they are mainly imitative ones, 
accounting for more than half of the types of entrepreneurial activities, while the proportion of entrepreneurial types with intellectual property rights as the main elements of entrepreneurship or business model innovation is relatively low. This reflects that in the current college students' entrepreneurship, there are still many deficiencies in promoting the transformation of scientific and technological achievements by innovation.

\section{Suggestions on Improving the Effectiveness of College Students' Entrepreneurship}

\subsection{Colleges and Universities Should Strengthen \\ Entrepreneurship Education and Improve the Effectiveness of Entrepreneurship Service}

Entrepreneurship education is a window for college students to form entrepreneurial cognition and expand entrepreneurial knowledge [8]. It is also an effective carrier for college students to establish entrepreneurial interest and improve their entrepreneurial willingness. It is also an effective platform to publicize entrepreneurship policies and provide entrepreneurial services. The quality of entrepreneurship education is directly related to the formation of College students' entrepreneurial intention and the proportion of their entrepreneurial willingness transformed into entrepreneurial behavior [9]. At present, in the "mass entrepreneurship and innovation" environment, all colleges and universities are carrying out and promoting entrepreneurship education. The overall effect of entrepreneurship education is constantly improving, but there are still many deficiencies, which need to be strengthened from the following aspects: first, the way of entrepreneurship education needs to be innovated. At present, most of the entrepreneurship education courses in Colleges and universities are still based on traditional classroom teaching, which should be enriched and enriched in the future Innovation and entrepreneurship education mode, so that students can feel the entrepreneurial process of situational experience [10]; second, in the allocation of entrepreneurial teachers should be more diversified, should hire more experienced mentors to enter the entrepreneurship education classroom; third, entrepreneurship education, entrepreneurship practice and entrepreneurship services should be effectively connected to form "knowledge $\rightarrow$ practice $\rightarrow$ service $\rightarrow$ market" "Entrepreneurship education is mainly to impart knowledge and undertake the functions of popularization of entrepreneurial knowledge and mobilization of entrepreneurial willingness [11]. Entrepreneurial practice should be targeted. According to students' entrepreneurial willingness and entrepreneurial type, different entrepreneurial practice environment and entrepreneurial practice training platform are provided. Entrepreneurship service mainly solves the difficulties of market, capital, policy and other aspects for students to learn
To provide guidance and help for the difficulties encountered in the process of entrepreneurship [12].

\subsection{The Government Should Strengthen the Publicity and Implementation of Relevant Policies}

Since the State Council officially promoted "mass entrepreneurship and innovation" in 2015, governments at all levels from the central government to the local government have issued various preferential policies on promoting "mass entrepreneurship and innovation", providing full policy support for youth entrepreneurship and innovation with college students as the main group [13]. Most provinces have implemented the College students' entrepreneurship guidance plan, and adjusted the job-hunting subsidies to Entrepreneurship subsidies improve the standard of entrepreneurship subsidies and expand the scope of entrepreneurial subsidies. Social insurance subsidies are given to college students who have carried out entrepreneurship activities according to the flexible employment personnel. At the same time, a relaxed entrepreneurial environment is provided in academic management. Through the establishment of a sound flexible school system, college students are allowed to retain their status and suspend their studies to start their own businesses. For college graduates who start their own businesses, they can enjoy the highest floating reduction and exemption policy stipulated by the state and enjoy tax preference. Generally speaking, college students are facing a better market environment and policy environment for entrepreneurship [14]. However, from our survey, the current situation of College Students' understanding of national policies is still very weak. In the future, the government should strengthen the publicity and implementation of policies from the following aspects: first, we should strengthen the publicity of relevant policies, especially with schools and new ones Second, accelerate the implementation of various policies, actively promote the implementation of various preferential policies, benefit every entrepreneur and entrepreneurial enterprise, and resolutely resist the formalism of implementing documents with documents and meeting with meetings; third, actively promote the reform of release, management and service, simplify the process of handling affairs, and promote the implementation of policies In the process of integration of multiple certificates, administrative and service fees will be reduced and the transaction costs of start-up enterprises in their establishment, establishment and production and operation will be reduced [15].

\subsection{The Society Should Establish a Public Opinion Environment That Encourages Entrepreneurship and Tolerates Failure}

Entrepreneurship itself is an economic activity with different degrees of risk, and the results of entrepreneurship are highly uncertain due to the influence of a large number of unknown factors [16]. From the actual cases of European and American countries with more mature market economy, the 
successful cases only account for a small part of all entrepreneurial activities [17]. Therefore, the whole society needs to support and tolerate the failure of entrepreneurship. Under the background of "mass entrepreneurship, mass innovation", the social encouragement and tolerance of entrepreneurship should be strengthened from the following aspects: first, increase the positive publicity of entrepreneurship activities, focusing on the concept and process of entrepreneurship, rather than just focusing on the results of entrepreneurship; second, create a good atmosphere for innovation and entrepreneurship by holding entrepreneurship competitions and entrepreneurship Training camp, entrepreneurial achievement display and other activities, build an entrepreneurial exchange platform, enhance the experience exchange between entrepreneurs, and form a range of public opinions to encourage entrepreneurship, tolerate failure, and promote mutual assistance through television, radio, online newspapers and other social media; third, optimize the support system for entrepreneurship guarantee, adjust the small guarantee loan to entrepreneurial guarantee loan, and reduce the innovation We should strengthen the credit support for college students' entrepreneurial enterprises, improve the credit evaluation mechanism of College Students' entrepreneurship, encourage social venture capital institutions to inject funds into venture enterprises, and establish and improve a scientific and reasonable entrepreneurial risk sharing mechanism and entrepreneurial failure protection mechanism with the participation of entrepreneurial enterprises, guarantee subjects, policy subjects and financial institutions.

\section{Conclusion}

This paper uses the method of questionnaire survey, taking Jiujiang University Students as the research object, and makes an empirical analysis on the influencing factors of College Students' entrepreneurial intention. The results show that the overall level of College Students' entrepreneurial willingness is high, but the proportion of entrepreneurial practice is low. Male students have higher entrepreneurial willingness than female students. College students with different professional backgrounds have different entrepreneurial intentions. Entrepreneurship education has a positive effect on the promotion of entrepreneurial willingness. The current entrepreneurial activities are mainly survival oriented entrepreneurship, with intellectual property as the main entrepreneurship The proportion of business model innovation is low. In order to further enhance the entrepreneurial willingness of college students and realize the transformation from entrepreneurial intention to entrepreneurial action, universities, government and society should work together: colleges and universities should strengthen entrepreneurship education and improve the effectiveness of entrepreneurship services; the government should strengthen the publicity and implementation of relevant policies; the whole society should establish a public opinion environment that encourages entrepreneurship and tolerates failure.

\section{Acknowledgements}

The Project Supported by Key Topics In The 13th Five Year Plan Of Jiangxi Education Science In 2018 (Grant no. 18ZD071 and Grant no. 18ZD074).

\section{References}

[1] Zhang xinrou. Construction of cultivation mode of innovation and entrepreneurship ability of college students [J]. Science and technology and innovation, 2020 (14): 105-106.

[2] Murong Bing. A Review Of The Influencing Factors Of College Students' Entrepreneurial Intention [J]. Educational Observation. 2015, 4 (10): 28-29.

[3] Duan Limin, Du Yueping. The influence of entrepreneurial environment on College Students' entrepreneurial intention: a re examination of GEM model [J]. Technical economy, 2012, 31 (10): $64-70+97$.

[4] Liwen Tan, Wenxiang Cao, Chenxin Song. Research On The Relationship Between Entrepreneurship Education And Entrepreneurial Intention Of College Students [J]. Technical Economy And Management Research. 2015 (11): 34-39.

[5] Jing Xu. Research On The Relationship Between Entrepreneurship Education And Entrepreneurial Intention Of College Students [J]. Economic And Trade Practice. 2018 (10): 337-339.

[6] Bai Yu. Research on entrepreneurship education system based on College Students' entrepreneurial intention $[\mathrm{J}]$. China market, 2016 (25): 74-75.

[7] Yongchuan Shi, Ying Huang, Jiatong Wang. Research On The Influence Of College Students' Creativity On Entrepreneurial Intention [J]. Research On The Influence Of College Students' Creativity On Entrepreneurial Intention. 2020, 40 (11): 91-98.

[8] An Jia, Shi zhukai, Lu Yang. Research on the status quo, influencing factors and cultivation mechanism of innovation and entrepreneurship ability of private college students -Based on 1398 survey data in Jilin Province [J]. Statistics and management, 2020, 35 (07): 78-83.

[9] Sun Wenqi, Meng Changyu, Wang Wenjian. Research on the curriculum system of innovation and entrepreneurship cultivation of applied university students [J]. Modern education management, 2020 (07): 75-81.

[10] Wang Shusheng, Shao Hua. Content construction and practice exploration of College Students' innovation and entrepreneurship psychology [J]. Forestry teaching, 2020 (07): 93-96.

[11] Zhang Huan, Xi Delong, Jia Tianyu. Exploration on the optimization of College Students' Entrepreneurship mechanism under the background of "mass entrepreneurship and innovation" -- a case study of universities in China [J]. Public standardization, 2020 (13): 155-156 + 158.

[12] Sun Dapeng, Zhao Wenjing. Opportunities and challenges for college students in innovation and entrepreneurship under the background of "Internet plus", [J]. Chinese and foreign entrepreneurs, 2020 (19): 141. 
[13] Liao Kangli, Wang Yuqin. Current situation and Countermeasures of College Students' Entrepreneurship under the background of "mass entrepreneurship and innovation" [J]. Science and technology entrepreneurship monthly, 2020, 33 (03): 129-133.

[14] Liu Ping, Liao Kangli. Research on entrepreneurship education mode based on dormitory unit -- Based on the perspective of "learning dormitory" [J]. Education theory and practice, 2014, 34 (36): 8-9.

[15] Xiao Guofeng, Wang Yuqin, Liao Kangli. Discussion on employment concept education of accounting major -- Taking
Accounting College of Jiujiang University as an example [J]. Friends of accounting, 2012 (16): 120-122.

[16] Liu Ping, Liao Kangli. Research on employment and entrepreneurship education in local universities from the perspective of entrepreneurial endowment [J]. Education and occupation, 2012 (15): 81-82.

[17] Xiao Guofeng, Liao Kangli. Research on the employment concept of college graduates under the background of mass higher education [J]. Journal of Changchun University of Technology (SOCIAL SCIENCE EDITION), 2011, 24 (12): $134-135+138$. 